\title{
溶射法による $\mathrm{Al}-8 \mathrm{wt} \% \mathrm{Fe}$ 急冷合金粉熱間押出し材の 機械的性質におよぼす焼鈍の影響についで
}

\author{
横田勝**, 上田太 次** \\ 黑田隼 雄***，庄 司 啓一郎 ${ }^{\dagger}$
}

Masaru Yokota, Taiji Ueda, Hayao Kuroda and Keiichiro Shoji: Influence of Annealing on Mechanical Properties of Flame Sprayed and Rapidly Solidified Al-8wt\%Fe Alloy Powder Fxtruded Materials.

Rapidly solidified Al-8 wt\%Fe alloy powders were produced by flame spraying method. The powders were cold pressed to billet and then hot-extruded at the temperature $573 \mathrm{~K}$ and the extrusion ratio of 41 to rod of $5 \mathrm{~mm}$ diameter. The influence of annealing of mechanical properties of extruded materials was investigated. Results obtained were as follows:

(1) Mechanical properties of as-extruded materials were as follows: tensile strength; $37 \mathrm{kgf} / \mathrm{mm}^{2}$, elongation; $9.5 \%$, proof strength $(0.2 \%) ; 27 \mathrm{kgf} / \mathrm{mm}^{2}$ and hardness; $100 \mathrm{kgf} / \mathrm{mm}^{2}$. These mechanical properties measured at room temperature were maintained up to $773 \mathrm{~K}$ of annealing for 1 hour. Beyond that, opposite to the increase of elongation, the other mechanical properties decreased with the annealing temperature.

(2) At the annealing temperature $773 \mathrm{~K}$, hardness was decreased rapidly with the prolong of annealing time. The same tendency against annealing time was observed in the X-ray diffraction experiment; the $\mathrm{X}$-ray intensity of $\mathrm{Al}_{m} \mathrm{Fe}(m=4.4)$ metastable phase was increased rapidly with the prolong of annealing time.

The mechanism of strengthening of rapidly solidified Al-Fe alloys is thought to be the dispersion strengthening, and fine $\mathrm{Al}_{m} \mathrm{Fe}$ particles formed during solidification might play a role of dispersoids.

(Received September 24, 1986)

\section{I 緒訔}

$\mathrm{Al}$ 基 $-\mathrm{Fe}$ 系急冷粉末の熱間押出し材または熱間鈠造 材は比強度や高温強度が高く，じん性も比較的に良好な ため, 開発段階ではあるが多くの研究亡実験が進められ ている．筆者らあ高合金急泠粉末の作製法として溶射ガ ンを用いて $\mathrm{Al}-\mathrm{Si}$ 系”および $\mathrm{Al}-\mathrm{Fe}$ 系 $^{2}$ に適用し，酎 者いずれも急冷微細組織の粉末を得ることができた。し たがって今回は前回得られた Al-8wt\% Fe 急冷粉末を用 いて熱間押出し材を作製し，その機械的性質におよぼす 焼鈍の影響について検討することを目的とした。

\section{II試料および実験方法}

本実験方法の流れ図は Fig. 1 亿示すとおりであり，ま ず出発原料よなる AI 粉扣よび Fe 粉は前報2 と同様, それぞれー250メッシュの噴䈻 $\mathrm{Al}$ 粉と平均粒徍 $2.5 \mu \mathrm{m}$ のカーボニル Fe 粉定として用い，また比較のために，

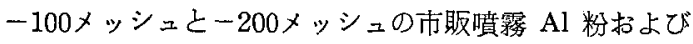
市販噴霧 $\mathrm{Fe}$ 粉香使用した. 以下の溶射急冷粉の作製工
程までは前報とまったく同様である。このようにして得 られた粉末を $3 \mathrm{t} / \mathrm{cm}^{2}$ の成形纴で一軸圧縮により $\phi 30$ $\mathrm{mm} \times 40 \mathrm{~mm}$ 高さの山柱状圧粉体とした．乙の場合の密 度比は約 $85 \%$ であった. この圧粉体を大気中 $673 \mathrm{~K} て ゙ 10$ 分間加熱してから，押出し用金型の内壁を潤滑剂として 黒鉛粉を機械油にり九濁させて叙布しておき，その中に 生粉体を押入してただちに押出しを開始した。押出し材 として $\phi 5 \mathrm{~mm}$ の線材を得るために押出し比を 41 とた。 機械的性質としては硬さ，引張り強さ，伸びおよび 0.2\%耐力を測定した. てれらの諸性質に対して室温か

ら $820 \mathrm{~K}$ までの範国内でそれぞれ 1 時間加熱空冷によ り室温まで泠却し，すべて室温で測定した。まず硬さは ロックウェル試験機を使用し，材料の硬さが下スケール とHスケール（荷重 $60 \mathrm{kgf}$, 鋼球の直径はそれぞれ3.17 および $1.59 \mathrm{~mm}$ ) に执よんでいたので単位を統一するた

* 昭和 61 年 5 月本協会音季大会飞て一部発表，昭和 61 年 9 月 24日受理.

** 大阪大学工学部金属材料工学科, $\bar{T} 565$ 吹田市山田丘2-1.

*** 東洋精機(株), 广660 尼崎南長洲本通2-1.

$\dagger$ 大阪大学工学部, 〔(現)近畿大学理工学部】. 


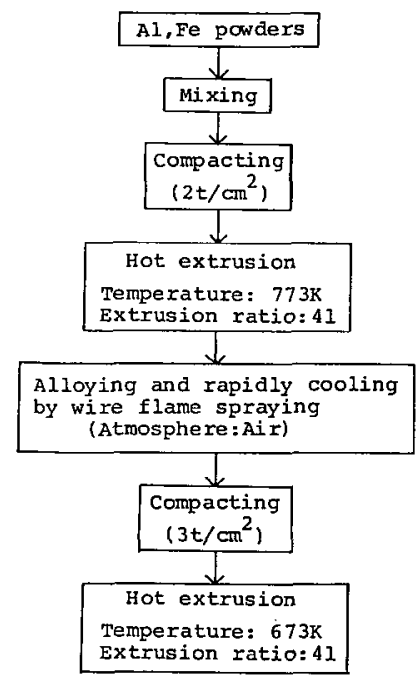

Fig. 1 Flow chart of production of hot extrusion $\mathrm{Al}-8 \% \mathrm{Fe}$ alloy.

めに，圧痕の直径を測微顕微鏡により測定してブリネル 硬さを求好際の関係式, $H=2 P / \pi D\left(D-\sqrt{D^{2}-d^{2}}\right)(P$ : 荷重, $D:$ 鎝球の直径, $d:$ 圧痕の直径) により硬さを $\mathrm{kgf} / \mathrm{mm}^{2}$ として表示した．硬さの測定面ば押出し方向 に直角な切断面である。

引張り強さ，伸び抢よび $0.2 \%$ 耐力の測定は押出し線 材を $40 \mathrm{~mm}$ 長さに切断し，旋盤により中心部約 $20 \mathrm{~mm}$ を断面が円形の平行部とした．との断面の直径は約 4.5 $\mathrm{mm}$ であった. 伸びは上記試験片に標点間距離を $15 \mathrm{~mm}$ として测定した．0.2\%耐力は応力一䄳み線図上から求め た.引張試験のクロスベット速度は $1.8 \mathrm{~mm} /$ 分の一定 である.

原料粉および熱間押出し材の微細組織は走筧型電子顕 微鏡 (SEM) によって観察した。ここで用いた腐食液は ケラー試薬である。また焼鈍䎲よる相変化を調べるため に溶射粉末を精製水素気流中 $773 \mathrm{~K}$ で10分から10時間 まで変化させた試料につき，X線デイフラクトメーター による回折図形加ら種々の金属間化合物の相対強度を求 め，それらの相対变化量を追跡した。本実験で得られた 急冷粉末には前報で述べたように安定相の $\mathrm{Al}_{3} \mathrm{Fe}$ 之準 安定相の $\mathrm{Al}_{m} \mathrm{Fe}(m=4.4)$ が主な化合物であることがわ かっているので, 皘分強度を求めるためのピークは他の 回折ピーク上重複しないように $\mathrm{Al}_{3} \mathrm{Fe}$ では回折角 $2 \theta=$ $21.85,21.98$ 㧍よび $22.42^{\circ}$ の 3 線を, $\mathrm{Al}_{m} \mathrm{Fe}$ では $2 \theta=$ 20.1 $1^{\circ}$ の回折線を使用した. ただしX線は $\mathrm{CuK} \alpha\left(\mathrm{K} \alpha_{1}=\right.$ 1. $54051 \AA, \mathrm{K} \alpha_{2}=1.54433 \AA$ ) を採用している.

\section{III 実験結果およひ考察}

まず溶射用線材の原料となる純 $\mathrm{Al}$ 粉および純 $\mathrm{Fe}$ 粉 の粒度に対する最終熱間押出し材の硬さ変化を焼鈍温度

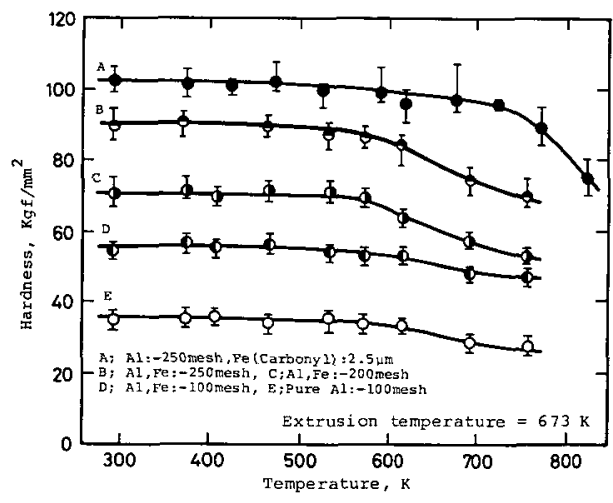

Fig. 2 Relation between Rockwell hardness (load $=60 \mathrm{~kg}$, diameter of steel ball $=3.17$ or $1.59 \mathrm{~mm}$ ) and annealing temperature for pure $\mathrm{Al}$ and $\mathrm{Al}-8 \mathrm{wt} \% \mathrm{Fe}$ extruded materials (Measurement were made on transverse sections annealed for 1 hour prior to each test).

を変えて比較した．Fig. 2 はその結果を示したものであ り，比較のために純 $\mathrm{Al}$ 粉の場合示してある。てれら 試料の作製工程はすべて同一であり，実験方法の項で述 べたとおりである、焼鈍温度は $825 \mathrm{~K}$ までの範团とし， 㶹鈍時間はすべて一定の1時間であり，室温にまで空冷 後硬さの測定を行っている. 図で示されるように純 $\mathrm{Al}$ に対して Fe を添加したものはすべて硬さは上界してい るが，とくに原料粉末の粒度が細かいものほどその効果 は大きい，てれ标すで報告したように゙”，原料粉末が 細かいものほど急冷粉の凝固組織屯微細となることに対 応するようである.とくに原料粉としてー250メッシュ の噴霧 $\mathrm{Al}$ 粉之平均粒径 $2.5 \mu \mathrm{m}$ のカーボニル Fe 粉を 使用したものでは室温での硬さが純 $\mathrm{Al}$ の硬さに対して 約 3 倍にもなり，焼鈍に上る硬さの低下があらわれる温 度は，他のあのでは 550〜600 K になるのに対して，乙 の場合では約 $725 \mathrm{~K}$ までほとんど変化しないという良 好な結果を得た。

つぎに熱間押出し材の各種機械的性質に対する焼鈍の 影響について得られた結果をまとめて Fig. 3 に図で示

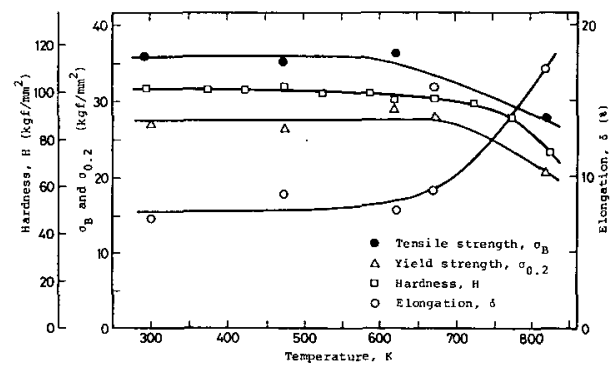

Fig. 3 Mechanical properties of Al-8 wt \% Fe extrusions (Measurements were made on transverse sections annealed for 1 hour prior to each test). 
す. 各性質は約 $620 \mathrm{~K}$ までの範囲で 1 時間の加熱によ っても初期の值とほとんど変わらず，引張り強さ，硬さ および耐力は約 $620 \mathrm{~K}$ まで保持されるが, との温度を 過ぎるとこれらの值は漸減する．伸びあそれに対応して 約 $650 \mathrm{~K}$ までは初期の值を保つが，それ以上では著し い伸びを示す.ここで各機械的性質は約 $620 \mathrm{~K}$ までほ とんど変わらず一定值を示すが，それらの值はそれぞれ 引張り強さは約 $37 \mathrm{kgf} / \mathrm{mm}^{2}$, 硬さは約 $101 \mathrm{kgf} / \mathrm{mm}^{2}$, $0.2 \%$ 耐力は $27.5 \mathrm{kgf} / \mathrm{mm}^{2}$, 伸びは7. $5 \%$ でった。

つぎに硬さに対する種々温度での燒鈍時間の影響を調 べた. Fig. 4 は機械的性質があっとも良好と思われる -250 メッシュの噴霧 $\mathrm{Al}$ 粉と平均粒径 $2.5 \mu \mathrm{m}$ のカーポ ニル $\mathrm{Fe}$ 粉を原料とした試料に関する結果である、焼鈍 温度は $423 \mathrm{~K}$ から $823 \mathrm{~K}$ までの範囲であり, 時間は最 高500時間までとした。烤鈍温度が高い $773 \mathrm{~K}$ と $823 \mathrm{~K}$ では硬さは焼鈍の初期で大きく低下するが, $573 \mathrm{~K}$ 以下 では約 100 時間まで増加の傾向を示し，焼鈍温度が中間 の $523 \mathrm{~K}$ と $573 \mathrm{~K}$ ではその後漸減し, 約 300 時間経過後 に出発点の硬さより低くなる. 焼鈍温度が低い $423 \mathrm{~K}$ と $473 \mathrm{~K}$ では約 100 時間後に最高となり，その值は 500 時 間までの範囲内ではほとんど低下しない。なお $573 \mathrm{~K}$ 以 下での焼鈍で硬さが漸増するのは, $\mathrm{Fe}$ が $\alpha-\mathrm{Al}$ 中に急冷 により過飽和に固溶し，その後の焼針によって時効析出 (その析出物は現段階では不明である) したためと考え られるが，いずれにしてもこの時効による強化の程度は 大きくはない.

ことで Al-8wt\% Fe 急冷粉を用いた熱間押出し材の主 として引張り強さに関する従来報告された主なすのを Table 1 にまとめて示す. ただし比較しやすいように押 出し温度は知れるかぎり $673 \mathrm{~K}$ でのデータを引用した. このような結果を比較する場合，急冷粉の製造法や押出 し比などがそれぞれの研究者らによって異なるので単純 ではないが，ただ押出し温度が同じ場合，押出し比を大 きく変化させないかぎり，機械的性質むほとんど変わら ないととが報告されているので,5), 引張り強さ，伸び, そして硬さは急冷粉製造時に採用した急冷法によって決 まるようである．押出しのままの状態で他の研究者らの

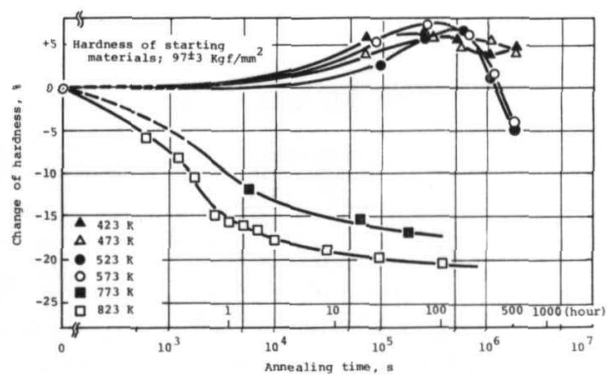

Fig. 4 Relation between hardness change and annealing time for the hot extruded $\mathrm{Al}-8 \mathrm{wt} \% \mathrm{Fe}$ alloy by using rapidly cooled alloy powders.

結果を比較するかぎりでは，本実験による引張り強さや 伸びの各性質は良好な材料の部類に入るもの之思わ机る。 これらの性質は Fig. 3 で示したように約 $650 \mathrm{~K}$ までの 温度範囲内で 1 時間の焼鈍によってあほとんど低下せず, 押出しのままでの状態を保持する.

Photo. 1 に引張り破面の SEM 像を示す. (a) および (b) には熱間押出しのままの試料について, (c)および (d) は押出し材を $773 \mathrm{~K}$ で 1 時間焼鈍した試料の引張り破 面である. (a)または (c) から明らかなように，これらの 試料は表面が大きな凹凸のある不均質な破面を示し，じ
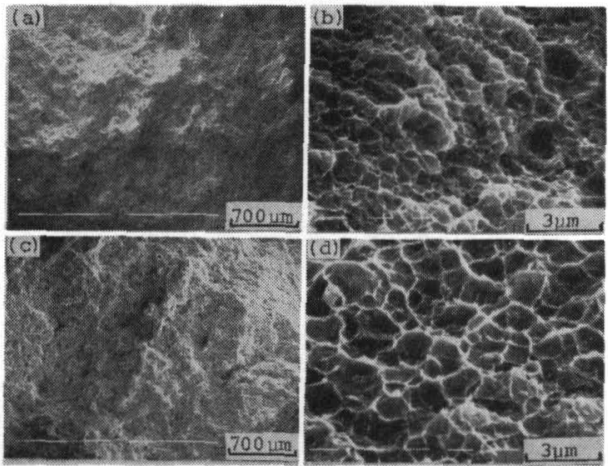

Photo. 1 Fractographs of rapidly solidified $\mathrm{Al}-8 \mathrm{wt} \% \mathrm{Fe}$ alloy powder extrusions; (a) and (b) : as-extruded at $673 \mathrm{~K}$, (c) and (d): annealed at $823 \mathrm{~K}$ for $3.6 \mathrm{ks}$ in $\mathrm{H}_{2}$ gas.

Table 1 Mechanical properties data of rapidly solidified $\mathrm{Al}-8 \mathrm{wt} \% \mathrm{Fe}$ alloy powder (foil) extrusion.

\begin{tabular}{l|l|c|c|c|c}
\hline $\begin{array}{c}\text { Authors } \\
\text { (reference in parentheses) }\end{array}$ & \multicolumn{1}{|c|}{$\begin{array}{c}\text { Production method } \\
\text { of powders (foils) }\end{array}$} & $\begin{array}{c}\text { Extrusion } \\
\text { temperature } \\
(\mathrm{K})\end{array}$ & $\begin{array}{c}\text { Extrusion } \\
\text { ratio }\end{array}$ & $\begin{array}{c}\text { Tensile } \\
\text { strength } \\
\left(\mathrm{kgf} / \mathrm{mm}^{2}\right)\end{array}$ & $\begin{array}{c}\text { Elongation } \\
(\%)\end{array}$ \\
\hline Shibue et al (4) & Gas atom. & 673 & 15 & 15 & 20 \\
Thursfield et al (5) & Splat cooled & 673 & 8 & 38 & 12.5 \\
Bryukhovets et al (6) & Gas atom. & 673 & - & 35 & 10 \\
Akechi et al (7) & Air atom. & - & - & 38 & 3 \\
Arnhold et al (8) & Splat cooled & 673 & 23 & 30.6 & 19.3 \\
Towner (9) & Gas atom. (Al-7.6\%Fe) & - & - & 32 & 16 \\
Esslinger et al (10) & Splat cooled (foil) & - & - & 22.7 & - \\
Present work & Air atom. & 673 & 41 & 37 & 7.5 \\
\hline
\end{tabular}


ん性が劣るように思われるが, (b) の高倍率写真で観察さ れるように微細なディンプルが全面を被っておりり，ての ような性質が伸びを有するてとにつながっているあのと 思われる。このような傾向は Grant ら"11も報告してお り, $\mathrm{Al}$ 系急冷粉の熱間押出し材の特長とも思われる.

Photo. 1 (c) および (d) は熱間押出し材を $773 \mathrm{~K}$ で 1 時 間燒鈍した後の引張り破面であり, 低倍率による破面は やはり大きな凹凸状であるが，微視的には焼鈍によるじ ん性の改善があらわれ，ディンプルパターンがいく分大 きくなっているのがわかる.

このように $\mathrm{Al}-8 \mathrm{wt} \% \mathrm{Fe}$ 急冷粉を用いた押出し材が高 温強度に優れていることは明らかであるが，その強化機 構についてはいまだ明らかでないように思われる．前 報2)で述べたように, 従来は $\alpha-\mathrm{Al}$ 中への $\mathrm{Fe}$ の過飽和固 溶による固溶体強化によって説明されていたか，本実験 では〜 $10^{5} \mathrm{~K} / \mathrm{s}$ の急冷によっても $\alpha-\mathrm{Al}$ 中への $\mathrm{Fe}$ の固溶 限の拡大はほとんどないものと結論し，また最近の $\mathrm{Al}-$ $\mathrm{Fe}$ の急冷組織に関する研究12 14) によってあ同様な方向 にあるようである（あちろん従来の研究報告にあ $\mathrm{Al}-\mathrm{Fe}$ 系急冷金属で $\alpha-\mathrm{Al}$ 中に $\mathrm{Fe}$ はほとんど固溶しないとの 報告ああった)．またてのような $\mathrm{Al}-\mathrm{Fe}$ 系急冷金属の強 化機構について最近は分散強化機構が有力視されてい る4,99.筆者らあそのような立場に立つあのであるが，強 化に寄与する分散相は何かについてはまた研究者らによ って意見が分かれるところである.すなわち急冷凝固時 に $\alpha-\mathrm{Al}$ 中に晶出した安定相としての $\mathrm{Al}_{3} \mathrm{Fe}^{15}, \alpha-\mathrm{Fe}^{144}$,

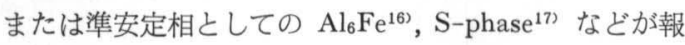
告されている. 本実験で得られた $\mathrm{Al}-8 \mathrm{wt} \% \mathrm{Fe}$ 急冷粉中 にはX線回折実験で知るかぎり, 安定相としての $\mathrm{Al}_{3} \mathrm{Fe}$ 之準安定相の $\mathrm{Al}_{m} \mathrm{Fe}^{*}$ および微量の $\mathrm{Al}_{6} \mathrm{Fe}$ が検出され た. $\mathrm{Fe}$ 含有率によって様子は異なるが, この合金系を 比較的ゆっくり冷却した場合には安定相の $\mathrm{Al}_{3} \mathrm{Fe}$ が晶 出し, 中間の泠却速度でのみ $\mathrm{Al}_{6} \mathrm{Fe}$ が晶出可能であ $り^{201}$, それより速い速度でのみ $\mathrm{Al}_{m} \mathrm{Fe}$ が晶出するとされ ている ${ }^{21,22)}$. したがって高温強度を高める分散相の役割 りを果たしているのは $\mathrm{Al}_{m} \mathrm{Fe}$ が最あ有力と考えられる. その目的で熱間押出し材を $773 \mathrm{~K}$ で種々時間焼鈍した 場合の硬さの変化と $\mathrm{Al}_{m} \mathrm{Fe}$ および $\mathrm{Al}_{3} \mathrm{Fe}$ の回折ピーク の変化を測定した. その結果を Fig. 5 に示す. ただし $\mathrm{Al}_{3} \mathrm{Fe}$ の回折ピークは $2 \theta=21.85^{\circ}, 21.98^{\circ}$ および $22.42^{\circ}$ の 3 線を, $\mathrm{Al}_{m} \mathrm{Fe}$ に関しては $2 \theta=20.1^{\circ}$ のあのを使用し

\footnotetext{
* 準安定相の $\mathrm{Al}_{m} \mathrm{Fe}$ と関してはその結晶構造は bct とされて いるが ${ }^{18)}$, 詳細はほとんど明らかとされていない. 前報2)で 述へたようと本実験では鈴木ら ${ }^{19)}$ の実験結果を参照して $\mathrm{Al}_{m} \mathrm{Fe}$ を確認したが, $\mathrm{Al}_{m} \mathrm{Fe}$ と断定するとは到っていない. なぜならばつぎの Fig. 5 と示す回折図形から回折角 $2 \theta$ が $20.1^{\circ}$ と $25.5^{\circ}$ では鈴木らの結果とよく一致するが, $2 \theta=$ 41. 5 4 $43^{\circ}$ では回折角度と強度が一致していない。 またこれ あ Fig. 5 と示されているが， $2 \theta=37^{\circ}$ 付近に弱い強度の不 明なピークが存在することあ事実である.
}

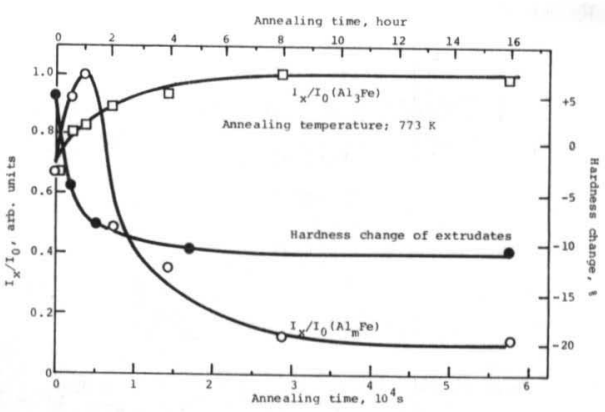

Fig. 5 Influence of annealing time on the $\mathrm{X}$-ray intensity of $\mathrm{Al}_{3} \mathrm{Fe}$ and $\mathrm{Al}_{m} \mathrm{Fe}(m=4.4)$ for the as flame sprayed powders and the hardness change for the as extruded material.

た. 硬さの変化に対する両化合物の相対強度の変化を比 較すると, $\mathrm{Al}_{3} \mathrm{Fe}$ 強度の変化は硬さの変化とあまり対応 しないようであるが, $\mathrm{Al}_{m} \mathrm{Fe}$ 強度は $773 \mathrm{~K}$ で約 1 時間ま での範囲内で急激に増大し，その後著しい減少を示す. このような変化と硬さの変化は一見して対応しないよう に思われるが，焼鈍時間 1 時間までの $\mathrm{Al}_{m} \mathrm{Fe}$ ピーク強 度の急激な増大と硬さの急激な低下はよく対応している ように思われる. したがって分散強化に寄与する晶出相 は他に見当らないのでこの準安定な $\mathrm{Al}_{m} \mathrm{Fe}$ が分散相の 役割りを果たしている可能性が高い，ただし硬さの低下 と $\mathrm{Al}_{m} \mathrm{Fe}$ の増大とがどのように関わっているのかは全 く不明であるが, 母相の $\alpha-\mathrm{Al}$ と $\mathrm{Al}_{m} \mathrm{Fe}$ 分散相との整 合性の立場から説明できるととあ考えられるが18)，いず れにしてあ今後の課題として残される. Photo. 2 は $\alpha-\mathrm{Al}$ 母相の透過電顕写真であり, $0.1 \sim 0.2 \mu \mathrm{m}$ の板状分散相 が観察される. この微粒子の種類と結晶構造は解析を行 っていないので不明である. てのような $\mathrm{Al}-\mathrm{Fe}$ 系急冷 合金の晶出微粒子の電顕による解析はいくつかの報告 があり, 安定相としての $\mathrm{Al}_{3} \mathrm{Fe}^{15)}$, 準安定相としての $\mathrm{Al}_{6} \mathrm{Fe}^{16)}, \mathrm{Al}_{m} \mathrm{Fe}(\mathrm{m}=4.4)^{21,23)}, \mathrm{Al}_{x} \mathrm{Fe}(x=5)^{24)}$ があげ られるが, $\mathrm{Al}_{m} \mathrm{Fe}$ を除く他の化合物は冷却速度が比較的 低い場合にのみ晶出するといわれており ${ }^{20,21,25)}$ ，また冷 却速度の低い合金粉末を用いた場合には強度も上がら ないととと関連させるとやはり高温強度を高めるのは

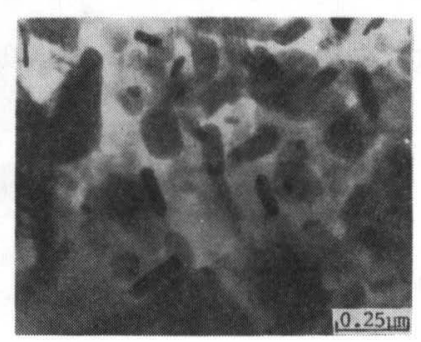

Photo. 2 Transmission electron micrograph of rapidly cooled $\mathrm{Al}-8 \mathrm{wt} \% \mathrm{Fe}$ alloy powder extrusion at $673 \mathrm{~K}$. 
$\mathrm{Al}_{m} \mathrm{Fe}$ 相の可能性が十分と考えられる.ただしての $\mathrm{A} l_{m} \mathrm{Fe}$ 相についてはいまだ十分明らかとなっておらず, また一力では微細な非晶質に近い $\mathrm{Fe}$-rich の $\alpha-\mathrm{Al}$ 相の 存在が最近報告されている ${ }^{26)}$. 要するにこの急冷合金の 強化機構は今だ明らかにされていないと考えるのが要当 と思われる.

$$
\mathrm{N} \text { 結 言 }
$$

溶射法による $\mathrm{Al}-8 \mathrm{wt} \% \mathrm{Fe}$ 急冷粉を用いた熱間押出し 材の機械的性質に执よぼす焼鈍の影響について夷験之㭘 討を行った．得られた結果を以下に要約する。

(1)押出し湜度 $473 \mathrm{~K}$, 押出し比 410 場合, 引張り強さ 37

$\mathrm{kgf} / \mathrm{mm}^{2}$, 伸び $9.5 \% ， 0.2 \%$ 耐力 $27 \mathrm{kgf} / \mathrm{mm}^{2}$, 便さ $100 \mathrm{kgf} / \mathrm{mm}^{2}$ となった。とれらの值は焼鈍時間を一. 定の 1 時間として脿鈍温度を種々変化させた場合, 約 $773 \mathrm{~K}$ までは室温での上記各值を保持したが, それめ 上の焼鈍温度では伸びは増大し，それ以外の性質は低 下の傾向を示した。

(2)焼鈍温度を一定の $773 \mathrm{~K}$ で焼鈍時間を変えて硬さと 準安定相 $\mathrm{Al}_{m} \mathrm{Fe}(m=4.4)$ の回折ピーク強度を比皎し たところ，硬さの急激な低下に対応して， $\mathrm{Al}_{m} \mathrm{Fe}$ 相の 回折ピーク強度が急激に增大するのか認められた。本 合金系（急冷の場合）の強化機構は分散強化に起因す るものと思われ，その分散相の役割りは急冷凝固時に 晶出した徽細な $\mathrm{Al}_{m} \mathrm{Fe}$ 相之思われるが断定的な結論 を得るには到らなかった。

最後に，本研究を遂行するにあたり，奉験の便宣をお 取りいただいた大阪府立工業技術研究所の辻栄次氏なら びに花立有功氏に心から感謝します。
文献

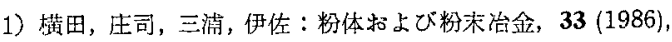
182.

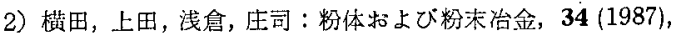
14.

3）横田, 浅倉, 庄司：粉体粉未冶金協会昭和60年度秋季大会 講演概要集, p 62 .

4) 涉江，佐野，山内，大丸：住友軽金属技報，26 (1985)， 75 .

5) G. Thursfield and M. J. Stowell: J. Mat. Science, 9 (1974), 1644.

6) A. A. Bryukhovets, N. N. Barbashin, M. G. Stepanova and I. N. Fridlyander: Poroshkovaya Metall, 1 (1970), 108.

7) 明智, 小谷, 黒石: 住友電気, [125] (1984), 186.

8) V. Arnhold and J. Baumgarten: Powder Met. Int., 17 (1985), 168.

9) R. J. Towner: Met. Progress, 73 (1958), 70.

10) P. Esslinger: Z. Metallkde., 57 (1966), 109.

11) M. Lebo and N. J. Grant: Met. Trans., 5 (1974), 1547.

12) H. Ichinose and H. Ino: "Proc. 5th Int. Confer. on Rapidly Quenched Met.", (1980), Würzburg, Germany, p 933.

13) P. Renaut and G. Lapasset: "Proc. 5th Int. Confer. on Rapidly Quenched Met.", (1980), Würzburg, Germany, p 815.

14) W. J. Boettinger, L. Bendersky and J. G. Early: Met. Trans., 17 A (1986), 781.

15) P. J. Blank: Acta Cryst., 8 (1955), 175.

16) L. K. Wolford: Acta Cryst., 18 (1965), 287.

17) W. H. Jacobs: J. Mat. Science, 9 (1974), 1631.

18）小菅：軽金属, $30(1980), 217$.

19）跉木，管野，田辽，䋆井：軽金属， 28 (1978), 284.

20) L. Backerud: Jernkontorets Annaler, 152 (1968), 109.

21）小菅, 水上：軽金属, 25 (1975), 48 .

22）浅見, 田中, 秀野: 僌金属, 28 (1978), 321.

23）小菅, 高田：軽金属，29(1979)，64.

24) R. M. K. Young and T. W. Clyne: Scripta Met., 15 (1981), 1211.

25) C. McL. Adam and L. M. Hogan: J. Austraillian Inst. Met., 17 (1972), 437.

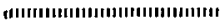 \\ 会 告

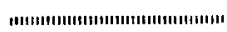

\section{第 3 回先端材料技術協会 (SAMPE Japan) シンポジゥム}

主 催：先端材料技術協会 (SAMPE Japan), シンポジ ウム委員会

協 賛：粉体粉末治金協会他

日 時：昭和62年12月 1日（火） 9:00 17:00

会 場 : 東京大学生産技術研究所講堂

定 員:100名
参加費 : 会員, 賛助会員, 協賛会䝿 $¥ 5,000$ (論文集代含む)

$\begin{array}{lll}\text { 一般 } & ¥ 7,000(\text { " }) \\ \text { 学 生 } & ¥ 3,000(\text { " })\end{array}$

内 容: 素材, 目的材, 技術それぞれの分野におけるオ リジナルな発表及び工学分野における境界技術 に関する萌芽的発表が行われる。

問合先：先端材料技術協会 (SAMPE Japan) 事務局 T141 品川区上大崎 3-1-5

目黑駅東口ビル301 TELO3(449)0091 